\title{
Identification of $\mathrm{C}_{5}^{+}$extraband of butyrylcholinesterase and two protein bands cathodic to it
}

\author{
F.D. Suyatna ${ }^{*}$, R. Setiabudy ${ }^{*}$, O. Tjandra $^{\dagger}$, E. $\operatorname{Herwana}^{f}$
}

\begin{abstract}
Abstrak
Pemeriksaan dengan elektroforesis pada plasma manusia menunjukkan 4 pita protein butirilkolinesterase $(B C h E), y a i t u C_{1}, C_{2}, C_{3}, C_{4}$ dan pada sejumlah individu juga suatu pita tambahan, $C_{5}{ }^{+}$. Selain itu selalu ditemukan juga adanya pita protein lain yang disebut pita " $S$ ". Untuk mengetahui apakah pita $C_{5}{ }^{+}$dan " $S$ " berhubungan dengan protein $B C h E$, kami melakukan analisis imunologi dan pemetaan peptida terhadap protein-protein ini. Cara imunologi dilakukan dengan membangkitkan antibodi poliklonal terhadap pitapita protein tersebut $\left(S_{1}, S_{2}, C_{4}\right.$ dan $\left.C_{5}^{+}\right)$dan direaksikan dengan protein plasma yang ditransfer pada kertas nitroselulosa. Antibodi individual tersebut bereaksi dengan semua pita protein yang diteliti termasuk $C_{4}$, yang merupakan isozim dari BChE, yang menunjukkan bahwa pita-pita protein tersebut mempunyai epitop yang sama. Beberapa pita protein yang terdapat pada posisi katodik terhadap $S_{I}$ juga bereaksi dengan antibodi, yang menunjukkan bahwa mereka mungkin merupakan fraksi protein BChE juga. Bila pita protein individual tersebut dicernakan dengan toksin $S$. aureus $V_{8}$ dan $\alpha$-kimotripsin, mereka menunjukkan derajat kesamaan yang tinggi dalam pola peptidanya. Penelitian ini menunjukkan bahwa pita protein $S_{1}, S_{2}$ dan $C_{5}^{+}$merupakan pita protein $B C h E$. (Med J Indones 2001; 10: 144-9)
\end{abstract}

\begin{abstract}
Electrophoresis of human plasma yields 4 butyrylcholinesterase (BChE) protein bands, i.e. $C_{1}, C_{2}, C_{3}, C_{4}$ and in some individuals also an extraband $C_{5}{ }^{+}$. In addition to that other protein bands called " $S$ " bands are also invariably detected. In order to know whether the $C_{5}{ }^{+}$ and the " $S$ " bands are related to the BChE protein, we have carried out immunological and peptide mapping studies on these proteins. The immunology approach was done by raising polyclonal antibodies against each protein bands $\left(S_{1}, S_{2}, C_{4}\right.$ and $\left.C_{5}^{+}\right)$and reacted to the plasma protein bands transferred on nitrocellulose papers. Individual raised antibodies recognized all protein bands studied including the $C_{4}$, an isozyme of $B C h E$, indicating that the protein bands contain similar epitopes. Several protein bands cathodic to $S_{1}$ also reacted with the antibodies, suggesting that they are probably fractions of the $B C h E$ protein, as well. When individual protein bands were digested with $S$. aureus $V_{8}$ toxin and $\alpha$-chymotrypsin, they revealed a striking similarity in peptide pattern among each other. These studies indicate that the $S_{1} S_{2}$ and $C_{5}{ }^{+}$protein bands belong to the BChE protein. (Med J Indones 2001; 10: 144-9)
\end{abstract}

Keywords: Butyrylcholinesterase, $\mathrm{C}_{5}^{+}$variant, immunodetection, peptide mapping.

Butyrylcholinesterase (EC 3.1.1.8, BChE) in the serum catalyses the hydrolysis of the muscle relaxant agent succinylcholine which is administered during general anesthesia. Patients with atypical type of this enzymes show abnormal response to succinylcholine, i.e. : prolonged apnoea which may last to, 1 hour, rather than the usual 3-6 min.

Electrophoresis of blood plasma, yields 4 protein bands, i.e. $\mathrm{C}_{1}, \mathrm{C}_{2}, \mathrm{C}_{3}$ and $\mathrm{C}_{4}$ and in some individuals also an extra-band $\mathrm{C}_{5}$. Based on the absence or the

\footnotetext{
" Department of Pharmacology, Faculty of Medicine, University of Indonesia, Jakarta, Indonesia

${ }^{\dagger}$ Department of Pharmacy, Faculty of Medicine, Tarumanagara University, Jakarta, Indonesia

${ }^{f}$ Department of Pharmacology, Faculty of Medicine, Trisakti University, Jakarta, Indonesia
}

presence of the extra band, an individual can be grouped into a $\mathrm{C}_{5}{ }^{-}$or a $\mathrm{C}_{5}{ }^{+}$variant. $^{2}$

During her experiment using acrylamide electrophoresis, Simpson ${ }^{2}$ discovered other protein bands which were called "storage" bands in addition to the $\mathrm{C}_{1}-\mathrm{C}_{5}$ bands. The "storage" bands, designated as " $\mathrm{S}$ " bands were seen in the electrophoresis of plasma samples that had been stored at $-20^{\circ} \mathrm{C}$; they were not apparent in fresh samples. In our study recently published, ${ }^{3}$ we also carried out a population study to determine the frequency of the $\mathrm{C}_{5}{ }^{+}$variant present in a Javanese ethnic group. Our results, however, revealed that fresh or stored samples invariably showed the presence of the " $\mathrm{S}$ " bands. It is the purpose of the present study to investigate whether the $\mathrm{C}_{5}{ }^{+}$and the "S" bands are immunologically and structurally identical to the $\mathrm{C}_{4}$ protein band. 


\section{METHODS}

Human blood samples of Javanese ethnic were collected from donors in the Indonesian Red Cross Service. ${ }^{3}$ The plasma obtained was directly assayed or stored at $-20^{\circ} \mathrm{C}$ until used. The distribution of $\mathrm{C}_{5}^{+}$ variant was determined by means of a polyacrylamide gel electrophoresis (PAGE) essentially as described by Laemmli, ${ }^{4}$ using a $7.5 \%(\mathrm{w} / \mathrm{v})$ acrylamide slab gel and a $3 \%(\mathrm{w} / \mathrm{v})$ acrylamide stacking gel in a vertical electrophoresis equipment, except that SDS and mercaptoethanol were omitted. The proteins were visualized by fast red. The results showed that among 398 individuals, there were $82(21 \%)$ of $\mathrm{C}_{5}{ }^{+}$variant. ${ }^{3}$ Fig. 1 depicts the $\mathrm{C}_{5}^{-}$and $\mathrm{C}_{5}^{+}$variants as shown by acrylamide electrophoresis. The protein bands investigated were the $\mathrm{C}_{4}$ and $\mathrm{C}_{5}$ bands and the upper 2 " $S$ " bands $\left(\mathrm{S}_{1}\right.$ and $\left.\mathrm{S}_{2}\right)$ cathodic to $\mathrm{C}_{5}$.

\section{Raising of Polyclonal Antibody}

In order to investigate whether the $S_{1}, S_{2}$ and $C_{5}$ extra bands were immunologically related to the $\mathrm{BChE}$ protein bands, polyclonal antibodies were raised. against the $\mathrm{S}_{1}, \mathrm{~S}_{2}, \mathrm{C}_{4}$ and $\mathrm{C}_{5}^{+}$protein bands. In brief, the procedure was carried out as follows: after preparative electrophoresis and visualization of the protein with fast red, the 4 protein bands were scraped out of the gel by means of a scissor. The protein bands were destained by incubation in SDS $3 \%$ and isopropanol $50 \%$ at $37^{\circ} \mathrm{C}$ for 24 hours. ${ }^{5}$ The solution was discarded and the protein bands were incubated in $0.1 \mathrm{~N} \mathrm{NaOH}$, overnight at $37^{\circ} \mathrm{C}$. The content of the protein in the eluates were found to be negligible; protein content of the eluate was determined as described by Peterson. ${ }^{6}$ Each protein band was homogenized with ultraturrax, mixed and vigorously vortexed with complete Freund adjuvant before subcutaneously injected between the scapulas of a rabbit. Booster injections using incomplete adjuvant were performed in weeks 2, 4 and 6 after the first injection. Five days after the last injection, blood was withdrawn via earvein of the rabbits. ${ }^{7}$

Since there were 4 protein bands studied 4 rabbits were needed to raise a spesific antibody against each band. The blood were centrifuged at low speed for $15 \mathrm{~min}$ and the plasma obtained were stored at $-20^{\circ} \mathrm{C}$ until used.

\section{Western Blot Analysis}

The antibodies obtained were used to examine whether the $S_{1}, S_{2}, C_{4}$ and $C_{5}$ bands were immunologically identical. After electrophoresis, the protein was transferred onto a Zeta-probe ${ }^{\circledR}$ blotting membrane by means of a Mini Trans-blot (BioRad) equipment set at $100 \mathrm{~V}, 250 \mathrm{~mA}$ for 6 hours. Immunodetection of the protein bands was performed using the method as described by Towbin et al. ${ }^{8}$

\section{Peptide Mapping}

Peptide patterns of the protein bands were investigated using toxin of Staphylococcus aureus $V_{8}$ and $\alpha$ chymotrypsin. Intragel protein digestion was carried out in a $7.5 \%$ of acrylamide ${ }^{9}$ in the presence of $2 \mathrm{ug}$ of toxin of $S$. aureus $V_{8}$ or $\alpha$-chymotrypsin. After electrophoresis the peptides were visualized by silver staining. ${ }^{10}$

Acrylamide and bis acrylamide were purchased from Nicalai Tesque (Japan), TEMED, ammonium persulfate, sodium dodecyl sulfate, glycine, Tween-20 and Zetaprobe ${ }^{\circledR}$ filter paper were from BioRad (USA). Fast red, silver nitrate, albumin, $\alpha$-chymotrypsin and buffer salts were from Sigma Co. (USA). Staphylococcus aureus $\mathrm{V}_{8}$ protease was from Pierce Chemical Co. USA.

\section{RESULTS}

Fig. 1 shows the protein pattern of $\mathrm{BChE}$ after gel electrophoresis; gel A of $\mathrm{C}_{5}^{-}$and gel $\mathrm{B}$ of $\mathrm{C}_{5}{ }^{+}$variants. The most two prominent bands in the lowest position in gel $\mathrm{B}$ were the $\mathrm{C}_{5}{ }^{+}$extra band and the $\mathrm{C}_{4}$ band, whereas in gel $\mathrm{A}$, the extra band was absent. The $\mathrm{C}_{1}$, $\mathrm{C}_{2}$, and $\mathrm{C}_{3}$ bands were faint in all samples. The assumed location of $\mathrm{C}_{1}, \mathrm{C}_{2}$, and $\mathrm{C}_{3}$ bands was depicted on the left side. This tentative location of the three bands was adopted from the data of Simpson. ${ }^{2}$ The source of several bands cathodic to $\mathrm{C}_{5}$ extra band was not clear. According to Simpson, ${ }^{2}$ the bands appeared after the serum was stored $\left(\right.$ at $-20^{\circ} \mathrm{C}$ ) and that fresh samples would show only the $\mathrm{C}_{4}$ band (and $\mathrm{C}_{5}$ bands, in $\mathrm{C}_{5}{ }^{+}$variant). However, in our hand, fresh samples gave a similar pattern as frozen samples. Antibodies raised against $S_{1}, S_{2}, C_{4}$, and $C_{5}$ bands were used to identify whether each antibody cross reacted with 
BChE bands. The similarity in peptide pattern was examined in all 4 bands $\left(\mathrm{C}_{4}, \mathrm{C}_{5}, \mathrm{~S}_{1}\right.$ and $\left.\mathrm{S}_{2}\right)$.
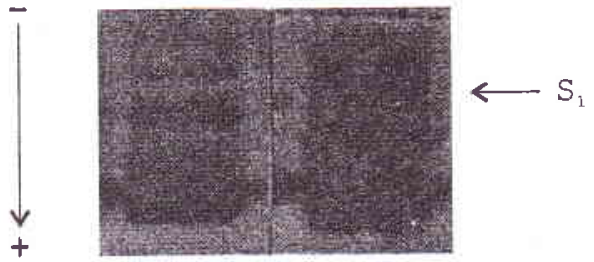

A

B

Figure 1. Polyacrylamide pattern of human plasma. Electrophoresis without SDS and mercaptoethanol was performed using a 7.5\% (w/v) acrylamide slab gel and a $3 \%(w / v)$ acrylamide stacking gel in a vertical electrophoresis equipment. The amount of samples applied onto the gel was $2 \mu l$ and the proteins were visualized by fast red azo dye.

Gel A : $C_{5}$ variant; $\mathrm{Gel} B: \mathrm{C}_{5}{ }^{+}$variant. An arrow indicates the position for $S_{1}$. The following proteins bands in downward direction are respectively the $S_{2}, C_{5}^{+}$and $C_{4}$.

\section{Western blot}

Fig. 2 shows protein bands of $\mathrm{C}_{5}^{+}$variant blotted on nitrocellulose papers after immunodetection. As we can see, individual antibody that was raised against $S_{1}$, $\mathrm{S}_{2}$ and $\mathrm{C}_{5}{ }^{+}$cross reacted with the band $\mathrm{C}_{4}$ and several bands cathodic to $S_{1}$ (nitrocellulose paper no. 1,2,3,4). The antibodies also recognized several bands anodic to $\mathrm{C}_{4}$. These protein bands, which were ill bordered were presumably the $\mathrm{C}_{1}, \mathrm{C}_{2}$, and $\mathrm{C}_{3}$ bands of $\mathrm{BChE}$.

The serum of non immunized rabbit did not react with any of the $\mathrm{BChE}$ protein bands (nitrocellulose $\mathrm{Bl}$ ). This result suggests that the $S_{1}, S_{2}$ and $C_{5}{ }^{+}$bands (and some protein bands cathodic to it) contained similar epitopes belong to the $\mathrm{BChE}$ protein $\left(\mathrm{C}_{4}\right)$.

\section{Peptide mapping}

Figs. 3 and 4 show peptide pattern of $\mathrm{S}_{1}, \mathrm{~S}_{2}, \mathrm{C}_{5}{ }^{+}$and $\mathrm{C}_{4}$ bands after digestion with the toxin of $\mathrm{S}$. aureus and $\alpha$-chymotrypsin, respectively. As can be seen, the peptide pattern of all protein bands shows striking similarities among each other. The immunodetection and peptide mapping analyses strongly support the suggestion that the $C_{5}$ extra band, $S_{1}$ and $S_{2}$ protein bands are isozymes or fragments of $\mathrm{BChE}$ protein.

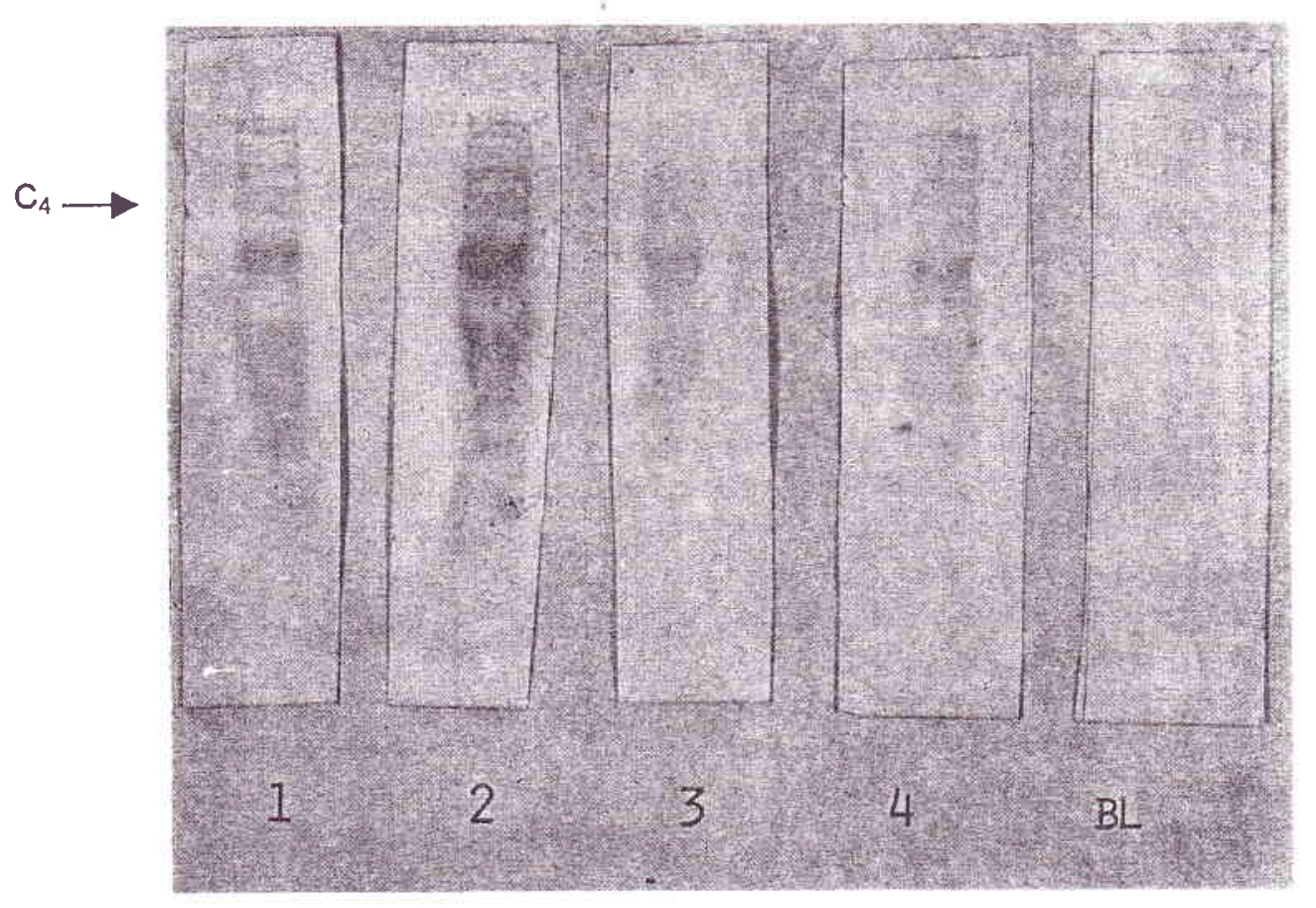

Figure 2. Immunodetection of $S_{1}, S_{2}, C_{5}^{+}$and $C_{4}$ protein bands. Individual antibody was raised against each protein band and reacted to the serum proteins of $C_{5}^{+}$variant blotted on a nitrocellulose paper. $S_{1}:$ lane $1 ; S_{2}:$ lane $2 ; C_{5}{ }^{+}:$lane $3 ; C_{4}:$ lane 4. Lane Bl was protein blotted-nitrocellulose paper reacted with serum of a non immunized rabbit. Blurred protein bands below $C_{4}$ are supposed to be the location for $C_{1} C_{2}$ and $C_{3}$ isozymes. 


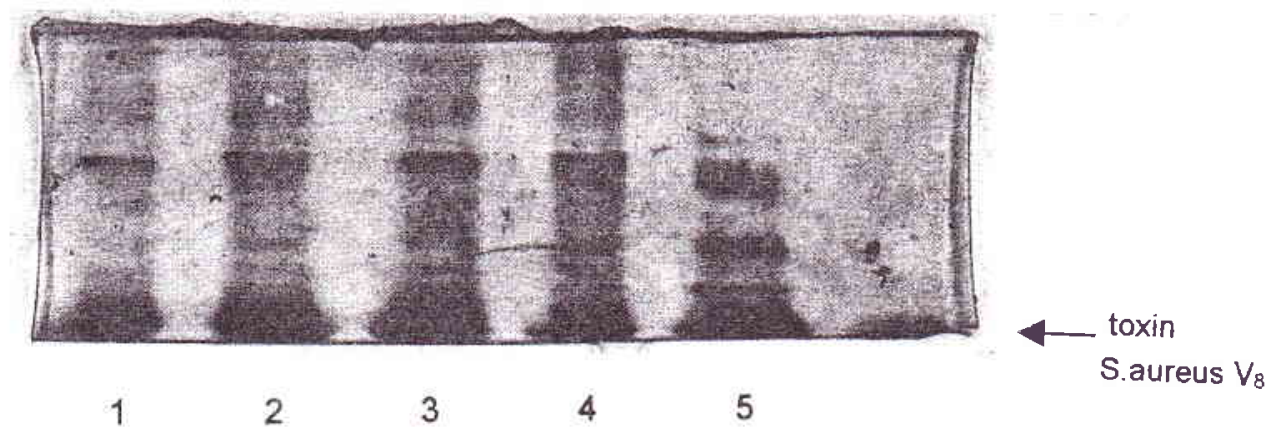

Fig. 3

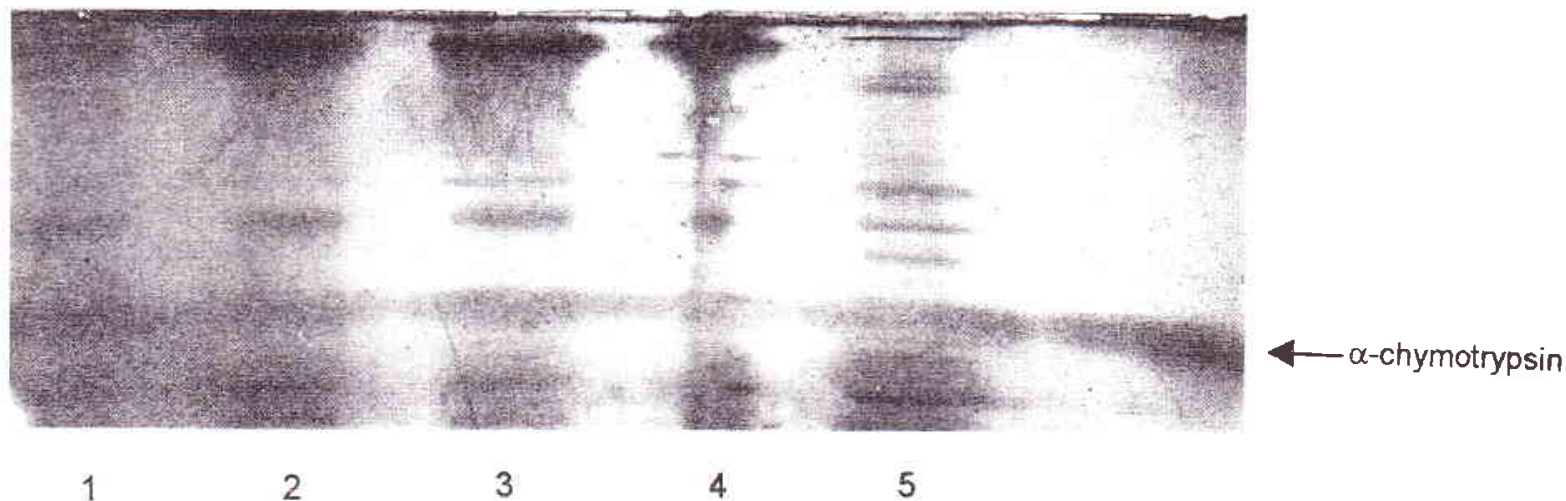

Fig. 4

Figure 3-4. One dimensional peptide maps of $S_{1}$ (lane 1), $S_{2}$ (lane 2), $C_{5}^{+}$(lane 3) and $C_{4}$ (lane 4).

Protein bands of interest were cut out of the gel by a scissor after electro-phoresis, applied onto the second gel and digested intragel with $2 \mu \mathrm{g}$ of toxin of $S$. aureus $V_{g}$ (Fig. 3) or $\alpha$-chymotrypsin (Fig. 4).

Lane 5 was the peptide pattern from a non-BChE protein band.

Arrows indicate the position for toxin of S.aureus $V_{s}$ and $\alpha$-chymotrypsin.

\section{DISCUSSION}

The $\mathrm{C}_{5}{ }^{+}$variant individuals were associated with the increased activity of $\mathrm{BChE}^{3,1]}$ and a lower mean adult weight. ${ }^{12}$ The presence of an extra band in the electrophoresis of plasma $\mathrm{BChE}$ of individuals with $\mathrm{C}_{5}{ }^{+}$variant has been a subject of investigation.

Two genetic loci, $\mathrm{CHE}_{1}$ and $\mathrm{CHE}_{2}$ have been proposed in the production of plasma $\mathrm{BChE}$. $\mathrm{CHE}_{1}$ encodes for the "normal" enzyme $\left(C_{1}, C_{2}, C_{3}\right.$ and $C_{4}$ isozymes) and $\mathrm{CHE}_{2}$ which is not allelic to the $\mathrm{CHE}_{1}{ }^{13}$ is associated with the expression of $\mathrm{C}_{5}$ band. ${ }^{11}$ Soreq et $\mathrm{al}^{14}$ using in situ hybridization of human chromosomes suggested $\mathrm{CHE}_{1}$ locus on chromosome 3 and $\mathrm{CHE}_{2}$ locus on chromosome 16 and that the $\mathrm{CHE}_{2}$ locus might be a pseudogene expressed only in $\mathrm{C}_{5}{ }^{+}$variants. However, according to genetic linkage studies, ${ }^{15}$ the $\mathrm{CHE}_{2}$ locus is linked to the $\gamma$-crystallin gene cluster (CRYG) on chromosome 2. Other linkage studies ${ }^{16}$ reported a loose linkage between haptoglobin (HP) on chromosome 16 and $\mathrm{C}_{5}\left(\mathrm{CHE}_{2}\right)$. 
However, recent determination of the structure of the $\mathrm{BChE}$ gene demonstrated that $\mathrm{BChE}$ is encoded by a single gene corresponding to the $\mathrm{E}_{1}$ locus. ${ }^{17}$

It has been suggested that the $\mathrm{C}_{5}^{+}$variant could be a hybrid molecule formed by the association of $\mathrm{BChE}$ (product of $\mathrm{E}_{1}$ ) with a different protein (product of $\left.\mathrm{E}_{2}\right),{ }^{18}$ or a modification of BChE by a neuraminidaselike enzyme. ${ }^{19}$

Plasma $\mathrm{BChE}$ on electrophoresis showed several protein bands, namely, $\mathrm{C}_{1}, \mathrm{C}_{2}, \mathrm{C}_{3}, \mathrm{C}_{4}$ and $\mathrm{C}_{5}$. In addition to that, there are several small protein bands appeared cathodic to $\mathrm{C}_{5}{ }^{+}$extra band. These protein bands which were described as "S" bands, ${ }^{2}$ might occur depending on storage ${ }^{20}$ partial proteolysis ${ }^{21}$ and /or electrophoresis condition. In the present study, we want to find out whether or not the "S" bands are the BChE protein. According to Simpson, ${ }^{4}$ there were 4 "S" bands observed after gel electrophoresis of frozen samples. In the present study, we could only detect 2 "S" bands which appeared consistently in fresh or frozen samples. Some bands of higher molecular weight were faint or could not be visualized at all. Considering this, we decided to carry out experiment to the two " $\mathrm{S}$ " bands just cathodic to the $\mathrm{C}_{5}{ }^{+}$band and denoted it as $S_{1}$ and $S_{2}$ bands, respectively. Our results demonstrated that an antibody raised against individual band $\left(S_{1}, S_{2}, C_{4}\right.$ or $\left.C_{5}\right)$ reacted with other protein bands. The antibody also recognized protein bands other than the 4 bands studied including the protein bands in location where the $\mathrm{C}_{1}, \mathrm{C}_{2}$, and $\mathrm{C}_{3}$ bands assumed to be. These results indicate that the protein bands $\mathrm{S}_{1}, \mathrm{~S}_{2}$ and $\mathrm{C}_{5}{ }^{+}$contain similar epitopes to the $\mathrm{BChE}$ protein band, $\mathrm{C}_{4}$.

In other studies, the 4 protein bands of interest $\left(S_{1}, S_{2}\right.$, $\mathrm{C}_{5}$ and $\mathrm{C}_{4}$ ) were scraped out, and were digested intragel in a second gel with $S$. aureus $V_{8}$ toxin and $\alpha$ chymotrypsin. The S.aureus protease cleaves at the carboxyl terminal side of aspartic and glutamic acid residues, ${ }^{22}$ whereas $\alpha$-chymotrypsin cleaves at the carboxyl terminal side of tryptophan, tyrosine, phenylalanine and leucine residues. ${ }^{23}$

As we can see in Figs. $3 \& 4$ the resulting mixtures as represented by peptide bands in gel electrophoretogram, is strikingly similar after proteolysis by specific proteases. On the other hand, a non-BChE protein band scraped out of electrophoresed plasma stained with Coomassie blue, gave different pattern. These results show strong evidence that the protein bands investigated are identical, i.e. they belong to the $\mathrm{BChE}$ proteins.

From this study we can conclude that the $\mathrm{C}_{5}{ }^{+}$bands and the " $S$ " bands $\left(\mathrm{S}_{1}\right.$ and $\left.\mathrm{S}_{2}\right)$ cathodic to the $\mathrm{C}_{5}{ }^{+}$ bands are identical to the $\mathrm{BChE}$ protein band $\left(\mathrm{C}_{4}\right)$.

\section{Acknowledgement}

We would like to thank Professor Bert N. La Du Jr. MD, $\mathrm{PhD}$ for the scholarship granted to Dr. F.D. Suyatna and the late Dr. S. Primo-Parmo for the valuable technical guidance. This study was partially funded by the RISBIN IPTEKDOK I 1996-1998, Ministry of Research and Technology, Republic of Indonesia.

\section{REFERENCES}

1. Lockridge O. 1992. Genetic variants of human serum butyrylcholinesterase influence the metabolism of the muscle relaxant succinylcholine. In: Sartorelli AC (ed). Pharmacogenetics of drug metabolism. Pergamon Press, New York, pp. 15-50.

2. Simpson NE. Polyacrylamide electrophoresis used for the detection of $\mathrm{C}_{5}{ }^{++}$cholinesterase in Canadian Caucasians, Indians, and Eskimos. Am J Hum Genet 1972; 24: 317 21.

3. Suyatna FD, Setiabudy R, Herwana E, Tjandra O. Butyrylcholinesterase and $\mathrm{C}_{5}{ }^{+}$variant in a Javanese ethnic group in Indonesia. Int J Clin Pharmacol Ther 2000; 38: 339-44.

4. Laemmli UK. Cleavage of structural proteins during the assembly of the head bacteriophage $T_{4}$. Nature $1970 ; 227$ : 680-5.

5. Ball EH. Quantitation of proteins by elution of Coomassie Brilliant Blue R from stained bands after sodium dodecyl sulfate-polyacrylamide gel electrophoresis. Anal Biochem 1986; 155: 23-7.

6. Peterson GL. A simplification of the protein assay method of Lowry et al. which is more generally applicable. Anal Biochem 1977; 83: 346-56.

7. Suyatna FD, Van Veldhoven PP, Mannaerts GP. Polypeptide pattern of isolated sarcolemma from normal and ischemic (autolytic) rat myocardium. Act Biochem Indon 1989; 1: 24-34.

8. Towbin H, Staehelin T, Gordon J. Electrophoretic transfer of proteins from polyacrylamide gels to nitrocellulose sheets : Procedure and some applications. Proc Natl Acad Sci USA 1979; 76: 4350-4.

9. Cleveland DW, Fischer SG, Kirschner MW, Laemmli UK. Peptide mapping by limited proteolysis in sodium dodecyl sulfate and analysis by gel electrophoresis. J Biol Chem 1977; 252: 1102-6.

10. Heukeshoven J, Dernick R. Increased sensitivity for Coomassie staining of sodium dodecyl sulfate polyacrylamide gels using Phast System Development Unit. Electrophoresis 1988; 9: 60-1. 
11. Harris H, Hopkinson DA, Robson EB, Whittaker M. Genetical studies on a new variant of serum cholinesterase detected by electrophoresis. Ann Hum Genet Lond 1963; 26: 359-82.

12. Chautard-Freire-Maia EA, Primo-Parmo SL, Picheth G, Lourenco MAC, Vieira MM. The isozyme of serum cholinesterase and adult weight. Hum Hered 1991; 41: 330-9.

13. Whittaker M. Cholinesterase (Vol. 11). In: Beckman L (ed). Monographs in human genetics. Karger, Basel, 1986.

14. Soreq H, Zamir R, Zevin-Sonkin D, Zakut H. Human cholinesterase genes localized by hybridization to chromosomes 3 and 16. Hum Genet 1987; 77: 325-8.

15. Eiberg H, Nielsen LS, Klausen J, Dahlen M, Kristensen M, Bisgaard MI, Moller N, et al. Linkage between serum cholinesterase $2\left(\mathrm{CHE}_{2}\right)$ and $\gamma$-crystalline gene cluster (CRYG) : Assignment to chromosome 2. Clin Genet 1989; 35: 313-21.

16. Lovrien EW, Magenis RE, Rivas ML, Lamvik N, Rowe S, Wood J et al. Serum cholinesterase $E_{2}$ linkage analysis: Possible evidence for localization to chromosome 16. Cytogenet Cell Genet 1978; 22: 324-6.

17. Arpagaus M, Kott M, Vatsis KP, Bartels CF, La Du BN, Lockridge O. Structure of the gene for human butyryl- cholinesterase. Evidence for a single copy. Biochemistry 1989; 29: 124-31.

18. Scott EM, Powers RF. Properties of the $\mathrm{C}_{5}$ variant form of human serum cholinesterase. Am J Hum Genet 1974; 26: 189-94.

19. Ogita ZI. (1975) In : Isozymes, Vol. II. Physiological Function (Markert CL, ed) pp 289-314, Academic Press, New York

20. Harris H, Hopkinson DA, Robson EB. Two-dimensional electropharesis of pseudocholinesterase components in normal human serum. Nature 1962; 196: 1296-8.

21. Lockridge O, La Du BN. Loss of the interchain disulfide peptide and dessociation of the Tetramer following limited proteolysis of native human serum cholinesterase. J Biol Chem 1982; 257: 12012-8.

22. Drapeau GR, Boily Y, Houmard J. Purification and properties of an extracellular protease of staphylococcus aureus. J Biol Chem 1972; 247: 6720-6.

23. Andrews AT. Peptide mapping. In: Gel electrophoresis of proteins (BD Hames, D Rickwood eds), $2^{\text {nd }}$ ed. Oxford University Press, Oxford, 1990, pp. 301-19. 